\title{
A representação da pornografia no discurso jornalístico
}

Júlio César Paula NEVES

Márcio Rogério de Oliveira CANO

\section{Considerações iniciais}

Em estudos desenvolvidos no Grupo de Pesquisa Leitura e Produção de Discurso (GPLPD/UFLA/CNPq), viemos analisando o discurso jornalístico e a forma como os estereótipos são construídos por meio do discurso da violência e do discurso do riso. Nesses estudos, percebemos que as representações do discurso pornográfico são atravessadas por tais questões, o que cria projeções negativas, colocando a pornografia em lugar marginalizado.

Geralmente a pornografia é associada a características pejorativas e vulgares, vista como indecente e imoral, porém, mesmo marginalizada, ela está presente na sociedade como material de 
consumo, como produto mercadológico na literatura, na internet, em filmes e novelas e em vários outros lugares. Assim, pode-se dizer que o discurso pornográfico, por um lado, está carregado desse olhar punitivo e violento, mas que, por outro lado, é difundido a partir de uma perspectiva monetária que vê a pornografia como produto muito rentável.

Como objetivos que orientam nossas discussões, buscaremos identificar as estratégias que se constroem dentro do discurso jornalístico para falar do discurso pornográfico e para criar essas representações negativas, e analisar a constituição de posicionamentos que colocam a pornografia em lugar marginalizado, portanto, atópico.

O corpus utilizado e que motivou esta proposta de estudo foi composto por reportagens extraídas da Folha de S. Paulo, a partir de busca pelo acervo digital que contém todas as edições do jornal arquivadas. A priori, delimitamos publicações no período de janeiro de 2014 a outubro de 2016, período em que a temática da pornografia teve grande destaque. A partir desse recorte, selecionamos dois discursos que fazem parte do material que constitui a nossa análise final.

\section{Por uma análise do interdiscurso}

Para os nossos estudos é necessário, primeiramente, compreender a noção de interdiscurso por considerarmos que o discurso jornalístico é marcado por traços interdiscursivos que revelam posicionamentos que envolvem o discurso pornográfico. Pela perspectiva de Maingueneau (2013), o interdiscurso tem precedência sobre o discurso. Isso significa propor que a unidade de análise pertinente não é o discurso, mas um espaço de trocas entre vários 
discursos convenientemente escolhidos. Com isso, pode-se dizer que existe comunicação entre alguns discursos e que isso faz parte do processo discursivo. Dessa forma, Bakhtin (1981 apud MAINGUENEAU 2008, p. 33) comenta que "o discurso reencontra o discurso do outro em todos os caminhos que levam a seu objeto, e não pode não entrar em relação viva e intensa com o outro". Assim, o discurso é atravessado por outros discursos e a partir dessa troca, começa a traçar seu caminho para a construção de sentidos e isso se dá por um corpus constituído.

Entende-se que é necessária essa relação entre vários discursos para a construção de sentidos de um determinado discurso se levarmos em consideração essa noção interdiscursiva. Ainda, segundo Maingueneau (2013, p. 62),

O discurso só adquire sentido no interior de um universo de outros discursos, lugar no qual ele deve traçar seu caminho. Para interpretar qualquer enunciado, é necessário relacioná-lo a muitos outros - outros enunciados que são comentados, parodiados, citados.

Essa ideia vai depender das especificidades de cada gênero, ou seja, o gênero escolhido vai ter características interdiscursivamente marcadas que são próprias: uma citação em um artigo científico é diferente de uma paródia de uma música, traços que vão compondo e sendo percebidos como interdiscurso na construção de sentidos. Com isso, utilizaremos o discurso jornalístico na qualidade de instrumento para percebermos como se efetiva esse espaço de troca entre outros discursos adequadamente escolhidos. 


\section{O jornalismo e seus poderes}

As pessoas sentem a necessidade de estarem sempre informadas a respeito de tudo o que acontece a sua volta. Isso se intensifica a cada dia, a partir dos recursos que são oferecidos, para que as informações cheguem cada vez mais rápidas. Seja através de revistas, jornais, televisão ou internet, o público é alvo de informações a todo o momento, e por isso pode-se dizer que a imprensa tem papel fundamental nesse processo de comunicação. Com o intuito de ampliar as discussões acerca do discurso jornalístico, buscamos os conceitos em Marcondes Filho (1989), Medina (1988) e Charaudeau (2007).

Para se manter nesse lugar, diz-se que o jornalismo figura como prática social dentro de um sentido mercadológico e que intenta à troca de informações pelo dinheiro do leitor. Dessa forma, a fim de instigar o sujeito a adquirir o produto, são incorporados no conteúdo do jornal ou revista informações intrigantes para que a troca se efetive. Nesse sentido, Marcondes Filho (1989) aponta que o jornal, possuidor dessas informações, detém uma parcela de poder e que essa relação é implícita e de dominação.

Junto ao saber transmitido reservadamente dos seus possuidores socialmente confirmados, estes detêm também sua parcela de poder. Informação significa também poder, e no jogo com sua utilização estão implícitas relações de dominação. [...] O saber aqui é negociado e serve como moeda para a ascensão na escala hierárquica da sociedade. Os escribas no mundo antigo ocupavam um posto privilegiado porque somente eles monopolizavam a capacidade de registrar e de saber. (MARCONDES FILHO, 1989, p. 24)

A perspectiva de Marcondes Filho (1989) faz-nos perceber que existe certo tipo de dominação entre o jornalismo e a sociedade, colocando o discurso jornalístico em posição de credibilidade e 
privilégio. O lugar que o jornalismo ocupa lhe concede poderes de manipular ou apresentar as informações que lhe convierem, de forma que atenda a seus interesses. Marcondes Filho (1989, p. 39) pontua que "o tratamento que sofre a notícia antes de chegar ao receptor é o principal modo de se operar a chamada 'manipulação' jornalística”.

Logo, podemos considerar que o jornal ocupa um espaço de controle e que existem discursos legitimados e não legitimados. Esses discursos passam por um lugar social em que supomos a existência de relações de poder do jornal atrelado à forma com que a mídia se posiciona, significando-se, por algum modo de dizer, no interior do discurso. De acordo com Charaudeau (2007, p. 131),

O espaço social é uma realidade empírica composta, não homogênea, que depende, para sua significação, do olhar lançado sobre ele pelos diferentes atores sociais, através dos discursos que produzem para torna-lo inteligível.

Pela perspectiva de Charaudeau (2007), é possível afirmar que, nesse espaço social, a mídia mostra-se com aspecto manipulador e faz com que o jornal aponte uma relação violenta ao apresentar, nesse caso, a pornografia como espaço decadente e estigmatizado. Isso nos faz perceber de que forma o jornal representa os discursos que circulam na sociedade, a partir do que podemos entender como discursos legitimados ou não.

\section{Discursos tópicos e discursos atópicos}

Pensar nos discursos que circulam na sociedade é levar em consideração a tolerância e o reconhecimento desses discursos como pertencentes ou não a essa sociedade. Maingueneau (2010) 
levanta questões acerca de discursos tópicos, paratópicos e atópicos para exemplificar as possibilidades de existência e o lugar de legitimação onde circulam tais discursos.

Entendem-se como tópicos aqueles discursos reconhecidos pela sociedade. Segundo Cano (2012, p. 48), fundamentado em Maingueneau, discursos tópicos:

[...] são aqueles discursos equivalentes ao que dizemos do campo discursivo. São existentes e legitimados socialmente, mas que, para conseguir essa legitimação, recorrem a outros discursos, pois não possuem o poder de se autolegitimarem, pois não são discursos constituintes, mas sim constituídos a partir de outros.

Contudo, para Maingueneau, entre os discursos reconhecidos pela sociedade, devemos fazer uma distinção entre discursos tópicos e discursos paratópicos.

Os discursos "paratópicos" (particularmente os discursos religioso, filosófico, literário, científico) servem de garantia aos outros, os discursos "tópicos", porque eles devem se localizar, simultaneamente, na sociedade e fora dela (MAINGUENEAU, 2010, p. 23).

Por isso, entende-se como discurso paratópico aquele que se situa na sociedade e que faz fronteira com o indizível e o absoluto, mas que, ainda segundo Maingueneau (2010, p. 23), só ocupa esse lugar "porque seus falantes mais prestigiosos são impulsionados por alguma força transcendente.. 
Por fim, faz-se necessário tratar do conceito de discurso atópico, pois, segundo o autor, nesse lugar o discurso pornográfico circula. Maingueneau (2010, p. 23) ressalta que "poderíamos classificar de discursos atópicos essas práticas que, tal como a pornografia, de alguma maneira, não têm lugar para existir, que se esgueiram pelos interstícios do espaço social.”.

Em função de como se pode perceber o discurso atópico, podemos pensar em uma temática cuja inserção no espaço social se dá de maneira problemática por não ter um lugar legitimado na sociedade e por circular sempre à margem. Isso não quer dizer que esses discursos não existam, mas significa que estão presentes na sociedade a partir de outra perspectiva, não sendo assumidos, tais como os discursos homofóbicos, machistas, misóginos, racistas entre outros que não são bem vistos socialmente.

Partindo do pressuposto que esses discursos circulam no corpo social, ressaltamos a percepção da dupla impossibilidade da pornografia que é tratada por Maingueneau. É impossível ela não existir e é impossível ela existir:

O primeiro impossível é da ordem do fato: diante do que é uma sociedade, é inelutável que esses enunciados serão produzidos nela. O segundo impossível é da ordem da norma: se esse discurso tivesse pleno direito de cidadania, então não haveria sociedade possível (MAINGUENEAU, 2010, p. 24).

Ou seja, da maneira pela qual funciona uma sociedade, seus meios orgânicos, pode-se dizer que é impossível ter um controle e excluir tais discursos da sociedade. Trata-se de uma construção natural quando se pensa no coletivo. Pela ordem da norma, seria 
difícil a aceitação da circulação desses discursos livremente, levando-se em consideração à própria perspectiva de Maingueneau supracitada em que por questões éticas e morais a pornografia é impossibilitada de circular livremente na sociedade como discurso aceitável.

\section{O discurso pornográfico e seu lugar marginalizado}

A circulação da pornografia sempre aparece na fronteira do lícito e do ilícito na sociedade. A abordagem de Maingueneau (2010) sobre o discurso pornográfico é uma importante referência na observação de como são construídas as relações que envolvem essa temática e o seu percurso sócio-histórico. Colocada em lugar à margem, a pornografia muitas vezes é sinônimo de imoralidade e perversidade, nunca assumida como pertencente à sociedade, $\mathrm{o}$ que pode ser entendido como espaço criminalizado. Isso se torna perceptível quando Maingueneau (2010, p. 9) descreve “o caráter eminentemente pejorativo do adjetivo 'pornográfico', cuja utilização basta para desqualificar tudo aquilo a que ele seja associado”. Ao utilizar os estudos de Maingueneau, é possível refletir sobre a atopia em que a pornografia se revela. $\mathrm{O}$ discurso pornográfico está ligado a essa relação entre a pornografia e sua circulação na sociedade; o problema, todavia, não é a pornografia, mas a relação social que a situa como categoria problemática e atópica.

O discurso pornográfico está intimamente ligado aos estudos sobre a sexualidade e, para refletir sobre tais questões, tomemos os estudos de Foucault. Para tanto, utilizamos os conceitos advindos de Foucault (1988) a fim de se demonstrar como a sexualidade é abordada e confrontada em relação ao discurso pornográfico. Foucault (1988, p. 12) trata desse tema com a afirmação de que "o sexo e seus efeitos não são, talvez, fáceis de decifrar; em compensação, 
assim recolocada, sua repressão é facilmente analisada”. A partir dessa perspectiva, pode-se dizer que trabalhar com a temática da sexualidade não é tarefa fácil, visto que esse assunto localiza-se em uma instância ainda muito segregada por limites obscuros na sociedade.

As perspectivas sobre a sexualidade e sobre a pornografia se entrelaçam entre as teorias de Maingueneau (2010) e Foucault (1988) quanto à presença da repressão ao tema, assunto a que se reserva lugar marginal na sociedade, o que poderemos compreender quando Foucault (1988, p. 14) afirma que

[...] o enunciado da opressão e a forma da pregação referem-se mutuamente; reforçam-se reciprocamente. Dizer que o sexo não é reprimido, ou melhor, dizer que entre o sexo e o poder a relação não é de repressão, corre o risco de ser apenas um paradoxo estéril. Não seria somente contrariar uma tese bem aceita. Seria ir de encontro a toda a economia, a todos os "interesses" discursivos que a sustentam.

Isto é, as discussões levantadas por Foucault colocam a sexualidade em um lugar reprimido e muitas vezes de difícil acesso pela forma com que é abordada. Pelas palavras do autor, as questões que envolvem a repressão da sexualidade se aceleram a partir do século XVIII e acontece a partir de uma lógica capitalista, em que uma ordem burguesa começa a dominar e controlar a forma com que a sexualidade circulava naquela época.

Observando a transformação da pastoral católica e do sacramento da confissão depois do Concílio de Trento, percebe-se um distanciamento e um silenciamento da nudez e de questões de se- 
xualidade que se encontravam nos manuais de confissão da Idade Média. Evita-se, então, tratar, na confissão, de assuntos com minuciosidade na explicação do que se considera pecado e ato contra a pureza, apagando-se das confissões as declarações dos fatos, das posições, dos gestos e de toda a situação que incitava o prazer e a sexualidade. A discrição passa a ser recomendada cada vez mais com insistência, entrando no campo da obscuridade, dando espaço ao que se aproximariam das regras da moralidade e da decência.

Pode-se dizer que essa temática ocupa um lugar sensível e restrito na sociedade, não sendo explanado de forma clara e simples, o que se aproxima do que Foucault (1988, p. 24-25) considera por hipótese repressiva.

Consideremos a evolução da pastoral católica e do sacramento da confissão, depois do Concílio de Trento. Cobre-se, progressivamente, a nudez das questões que os manuais de confissão da Idade Média formulavam e grande número daquelas que eram correntes no século XVII. Evita-se entrar nessa enumeração que, durante muito tempo, alguns, como Sanchez e Tamburini, acreditaram ser indispensável para que a confissão fosse completa: posição respectiva dos parceiros, atitudes tomadas, gestos, toques, momento exato do prazer - todo um exame minucioso do ato sexual em sua própria execução.

Contrastando a abordagem de Foucault e Maingueneau, pode-se perceber que gradativamente questões que envolvem tanto a pornografia quanto a sexualidade são colocadas à margem da sociedade e vistas por uma lógica de proibição e restrição. Quando essas questões são postas na sociedade, aparecem polidamente, ou seja, ocorrem apagamentos e interdições de certas palavras e expressões para que a sexualidade ocupe um lugar censurado na sociedade. Essa mudança pode ser vista como uma forma de tornar 
essas questões moralmente aceitáveis e tecnicamente úteis a partir de uma visão religiosa.

Pela perspectiva de Foucault, a sexualidade faz parte da natureza humana e não deveria ser tratada como um estigma, pois está intrinsecamente inserida na sociedade; é da natureza humana e não há como se desvencilhar do que é próprio e orgânico da humanidade. A sexualidade não deveria estar em uma posição marginalizada, mas ao contrário, deveria tratar-se de uma instância privilegiada e discutida na sociedade. Como diz Foucault (1988, p. 31), "o sexo não se julga, apenas administra-se". Ou seja, para o autor, o sexo deve ser assumido por discursos e ter lugar na sociedade. Com isso, pela perspectiva de um discurso pornográfico que é intrinsecamente ligada a esse assunto, a pornografia não deveria ser concebida por um olhar punitivo, mas deveria ser compreendida como uma instância presente na sociedade.

\section{Condições de produção}

Como ponto norteador, essa pesquisa apoia-se na Análise do Discurso $(\mathrm{AD})$ por tratarmos de uma área de estudos em que condições sócio-históricas e culturais da sociedade são levadas em consideração para analisar a construção de sentidos pelo discurso. A partir desse campo, podem-se discutir os problemas atrelados à sociedade e levantar questões a respeito de como o discurso é propagado e assumido por essa sociedade e como a língua é um instrumento que se apoia nos vários recursos disponíveis. Para fundamentar essa perspectiva, recorre-se a Maingueneau (2015, p. 30).

Quem se considera filiado à problemática discursiva associa intimamente língua (mais amplamente, os recursos semióticos disponíveis em uma sociedade), atividade comunicacional e co- 
nhecimento (os diversos tipos de saberes, individuais e coletivos, mobilizados na construção do sentido dos enunciados).

Compreende-se ainda, segundo as discussões de Maingueneau (2015), que a AD utiliza-se das três dimensões citadas acima e que, por isso, se distingue de outras disciplinas como a Sociologia, a Linguística Textual e a Psicologia. Por essa perspectiva, podemos compreender que a $\mathrm{AD}$, por considerar a construção do sentido dos enunciados, pode sustentar questionamentos advindos de problemáticas sociais em relação às condições sócio-históricas e culturais de produção dos discursos.

\section{A inserção da pornografia no contexto nacional}

Partindo do cinema como suporte de grande expressão, percebe-se que os filmes pornográficos ficaram fadados, durante anos, à clandestinidade. Só após a década de 60 com a revolução sexual que eles adquiram espaço e visualidade no mercado, mas não no Brasil. Segundo Luiz Carlos Merten, jornalista e crítico do cinema brasileiro,

[...] Na década de 60 com a revolução dos costumes com pílulas, minissaias, os Beatles e seja lá o que for, houve uma liberação muito acentuada dos costumes. No final da década em 1968/69 o movimento hipie estava proclamando "faça amor, não faça a guerra" o sexo livre era uma bandeira e é claro que o cinema acompanhou essa movimentação. ${ }^{9}$

9 Recorte de informação verbal do jornalista Luiz Carlos Merten em forma depoimento no filme "A primeira vez do cinema brasileiro" (2012). 
A fala do jornalista mostra, então, o início de um movimento que contribuiu para a expansão da pornografia nacional tendo como marco cinematográfico o filme "Coisas Eróticas" de Raffaelo Rossi em 1982.

Para elucidar os primeiros traços da pornografia nacional, utilizamos dados contidos no documentário "A primeira vez do cinema brasileiro" dirigido por Bruno Graziano e lançado no ano de 2012. O documentário faz referência ao filme "pornô" brasileiro "Coisas Eróticas" produzido por Raffaelo Rossi. Reconhecido como o primeiro longa-metragem de sexo explícito lançado no país, o filme rodava nas principais salas de cinema do Brasil, causando tumulto ainda na fase da ditadura militar e marcou a produção cinematográfica da época.

Pensando na expressão histórica da pornografia nacional, utilizamos a fala do jornalista e crítico de cinema André Barcinski ${ }^{10}$ "O filme Coisas Eróticas é um filme que tem uma importância histórica maior que cinematográfica. $O$ valor do filme não é, definitivamente, artístico. É principalmente histórico." Com isso, percebe-se a força da representação pornográfica em pleno regime militar, mesmo com toda a censura daquela época.

O documentário de 2012 também nos apresenta o filme de Raffaelo Rossi pela perspectiva de que, apesar de toda a censura repercutiu nacionalmente como um fenômeno cinematográfico. Pelas palavras de Cesar Robertho, um dos auxiliares da produção: "Foi uma loucura! Em São Paulo só se falava nisso. Filas quilométricas!" Ou seja, mesmo não sendo assumido pela sociedade, muita gente assistia e queria assistir ao filme. Isso se confirma na fala de Eduardo Rossi, filho do produtor "Eu acho que de sexo explícito foi o único que lançou 70 cópias em 70 cinemas do Brasil.”.

10 Recorte de informação verbal do jornalista e crítico de cinema André Barcinski em forma depoimento no filme "A primeira vez do cinema brasileiro" (2012). 
Segundo a mais importante empresa pública de cinema da América Latina, a extinta Embrafilme ${ }^{11}$, estima-se que cerca de 5 milhões de pessoas tenham assistindo "Coisas Eróticas". No entanto, pensando na clandestinidade do filme, há uma estimativa de que 25 milhões ${ }^{12}$ de espectadores tenham ido às salas de cinema. Outro dado interessante é que "Coisas Eróticas" custou apenas 2 milhões de Cruzeiros e rendeu mais de 1 bilhão e 500 milhões. Com isso, pode-se perceber de que forma a circulação pornográfica se constituía. Todos queriam assistir, ao passo em que a produção era marginalizada e era preciso fazer determinados esquemas para conseguir passar pela censura.

Esses dados apresentam o lugar social ocupado pela pornografia daquela época. Ainda de acordo com o documentário, o primeiro filme com cenas pornográficas cuja exibição foi "autorizada" pelo governo brasileiro é intitulado "O império dos sentidos”, produzido pelo cineasta japonês Nagina Oshima. O filme foi exibido na $3^{\text {a }}$ Mostra Internacional de São Paulo de 1979. A referida mostra cinematográfica ainda hoje tem grande expressividade nacional e no ano de 2016 realizou sua $40^{\text {a }}$ edição.

Ainda com base nas falas de atores contemporâneos presentes no documentário, pode-se dizer que houve um avanço nas produções pornográficas, bem como, na qualidade dos filmes, roteiros e outras inovações, contudo, não nos estigmas em que se esgueiram a pornografia. Consequentemente, essas produções, embora ainda continuem sendo representadas negativamente, a partir de um lugar marginalizado, se estabelecem como prática comercial em ascensão, que movimenta muito dinheiro.

11 Ver referência em: http://www.ctav.gov.br/2008/10/10/a-embrafilme/.

12 Dados presentes no documentário. 


\section{Resultados e discussão}

No percurso de constituição do corpus, a partir do período delimitado foram encontradas 159 páginas do jornal Folha de S. Paulo, no acervo digital, que continham assuntos relacionados à temática da pornografia. Em sua maioria, eram tratados temas como pornografia infantil, educação sexual, cinema pornô, indústria pornográfica, os efeitos da pornografia na juventude e o uso de redes sociais e anonimato. Outro dado relevante é que os textos encontrados circulavam por todos os cadernos do jornal, entre eles: Primeiro Caderno, Ilustríssima, Cotidiano, Revista Serafina, Ilustrada, Guia da Folha, Turismo e Folha 10. Com isso, compreende-se a recorrência da circulação do tema da pornografia no jornal e que essa presença não é fixa em apenas um tipo de caderno, mas por todo o jornal.

Uma questão interessante das reportagens selecionadas que compuseram o corpus é a utilização de falas dos personagens envolvidos. Isso nos remete ao que Maingueneau (2013) trata por discurso direto e discurso indireto em que os recursos discursivos utilizados podem revelar determinado tipo de posicionamento do enunciador. Neste contexto, Maingueneau (2013, p. 179) demonstra, a partir de sua teoria, que "toda forma de discurso relatado constitui uma enunciação sobre outra enunciação; põem-se em relação dois acontecimentos enunciativos: uma enunciação citante e uma enunciação citada." Com isso, pode-se dizer que os recortes que os jornalistas fazem das entrevistas constroem outros discursos, pois as relações e as representações são feitas pelos jornalistas e não pelos sujeitos presentes nas reportagens. Dessa forma, o poder da fala se encontra em posse do enunciador e não na fala dos personagens envolvidos.

O primeiro recorte faz parte da reportagem intitulada "A história da Brasileirinhas, a maior produtora de filmes pornográficos do Brasil (parte 1)" extraída da Folha de S. Paulo, publicada em 12 
de novembro de 2015. Na matéria, a repórter Marie Declercq narra seu contato com o ambiente e com as pessoas que encontrou na produtora "Brasileirinhas".

\section{Discurso 1}

(1) Uma garota aparentando 20 e poucos anos entrou na cozinha com olhar entediado. Seu porte é pequeno, curvilíneo, e a primeira coisa que chama atenção é seu cabelo liso e preto azulado descendo displicentemente até a bunda. O look casual, composto por um shortinho e uma baby look com a expressão "Brasileirinhas", escrita em letras garrafais, denota um momento de tranquilidade. "Vem almoçar", chama uma senhora. A jovem me olha e dá um imperceptível "Oi" antes de começar a comer seu PF (arroz, feijão, bife e salada) servido pela mulher encarregada do rango. Um homem próximo à mesa ativa uma webcam montada em frente à garota e olha para ela como se desse aval para começar. Notando que eu estava dividindo minha atenção entre a moça e a câmera, o homem me manda um sorriso e me avisa: "Aqui todo mundo quer ver tudo". Esse foi meu primeiro contato com a Brasileirinhas, possivelmente a maior produtora pornô do Brasil.

(2) (...) A tremedeira nas mãos revela certo grau de alcoolismo, que imediatamente é mencionado por ele, como se quisesse deixar tudo claro. Ele também adianta alguns detalhes que devem ser tópicos constantes de qualquer 
conversa inicial sobre sua função: "Não sou comedor, não sou desrespeitoso, e isso é só um trabalho como qualquer outro".

(3) Separado duas vezes (uma oficial e outra não oficialmente), Fábio conta que o "emprego não ajudou" nas relações. "Eu até tinha cuidado de levá-las [as mulheres] pro escritório e nas festas pra mostrar que é trampo mesmo, mas, nas filmagens de carnaval, quando você chega com 30 tipos de perfume diferentes e com lantejoula no seu corpo, até explicar isso já era”.

(4) Solteiro há três anos, Fábio é esclarecido quanto a relacionamentos. "Eu não me namoraria", admite, "assim como não namoraria uma mulher que posta todo dia fotos com homens sem camisa. Eu sou muito ciumento." (...).

(5) A segunda parte da reportagem será publicada em breve.

Observa-se no primeiro recorte do texto de Declercq que é feita uma ambientação do local e as primeiras impressões que a jornalista teve ao adentrar na casa onde ocorrem as filmagens da produtora Brasileirinhas. Para descrever esse ambiente e as pessoas presentes, foi utilizada como uma das estratégias linguístico-discursivas uma linguagem que a partir de um lugar-comum é compreendida como periférica e empobrecida, como no caso o uso da expressão "PF" para se referir à refeição da garota. A escolha por esse jogo de palavras não se dá ao acaso, o que Marcondes Filho (1989) propõe, 
[...] temos aqui a primeira forma de realizar jornalisticamente um seccionamento e uma seleção no conjunto de fatos sociais. O jornalista extrai da realidade o que lhe interessa (ou aos seus leitores) e isso se transforma em notícia: da realidade é extraída somente uma parte útil, sendo que essa utilidade é avaliada segundo objetivos puramente particularistas (MARCONDES FILHO, 1989, p. 50).

Pela perspectiva do autor, compreende-se que a escolha do vocabulário utilizado na matéria faz parte dos objetivos do jornalista em causar determinado efeito de sentido no leitor, ao que pudemos perceber a linguagem que circula entre as classes menos favorecidas e que foi utilizada cria certos estereótipos.

A forma com que a repórter descreve o cabelo e as roupas da garota contêm traços de rótulos que são impostos a pessoas que se encontram nesse ambiente repleto de clichês: "Uma garota aparentando 20 e poucos anos entrou na cozinha com olhar entediado. Seu porte é pequeno, curvilíneo, e a primeira coisa que chama atenção é seu cabelo liso e preto azulado descendo displicentemente até a bunda. O look casual, composto por um shortinho e uma baby look com a expressão 'Brasileirinhas' escrita em letras garrafais (...)”. O que se confirma com essa descrição não é uma profissional, não é um ambiente de trabalho, mas o estereótipo de um corpo que se vende e que se usa. O olhar entediado se contrapõe ao ambiente sexualizado, do fogo, do desejo. É comum imaginar prostitutas ou atrizes pornôs fazendo sexo por dinheiro, mas com cara de tédio, são traços estereotípicos. Esses traços combinam com as representações a seguir: "o cabelo liso e preto azulado... até a bunda... look casual... shortinho e baby look". Aqui, não temos uma mulher descrita, mas um olhar do jornalista que a confirma como atriz pornô, um corpo marginalizado. 
O momento da refeição da garota também é descrito a partir de trivialidades que incorporam à cena características que colocam os sujeitos nesse lugar desprivilegiado: "A jovem me olha e dá um imperceptível 'Oi' antes de começar a comer seu PF (arroz, feijão, bife e salada) servido pela mulher encarregada do rango". Pensando que se trata de um jornal de grande circulação nacional, pode-se dizer que há um posicionamento na escolha das expressões "PF (prato feito)" e "rango" e isso cria representações de pessoas que circulam em um ambiente desfavorecido, como se dissesse que quem possui alto poder aquisitivo não come "PF" e não faz parte desse contexto social. A atriz pornô come um rango, pensando que se fosse um empresário da indústria seria um almoço. Outro ponto, ainda no referido trecho, "A jovem me olha e dá um imperceptível 'Oi”' Será que tem alguém querendo se esconder? Esse imperceptível "oi” é passível de ser explorado de diversas formas: de uma jovem que se esconde por estar em um lugar marginalizado a uma jornalista que busca apagar a fala dessa jovem para dar ênfase à sua imagem estereotipada.

O trecho apresentado na sequência é composto por fragmento da entrevista da repórter com o porta-voz oficial da produtora, o diretor de marketing, Fábio Dias, conhecido na internet como "Fabão Pornô". O texto possui marcas discursivas que nos possibilitam observar algumas características que pretendemos abordar durante os estudos. Compreende-se que a reportagem, mesmo se propondo a falar sobre o universo da produção de pornografia, ocupa grande espaço falando sobre os traços do produtor quase como um personagem do imaginário de um submundo onde se produz filmes pornográficos.

Em (2) "A tremedeira nas mãos revela certo grau de alcoolismo, que imediatamente é mencionado por ele, como se quisesse deixar tudo claro", podemos perceber, de antemão, um sujeito que 
é colocado na situação onde um trabalhador atuante nesse local é estereotipado como alguém problemático. É necessário dar relevo ao trajeto da jornalista na sua narrativa, pois antes de o personagem falar de seu alcoolismo, ela aponta que a tremedeira da mão revela isso. É como se ela dissesse, não adianta esconder, eu já percebi, sua tremedeira não é normal, não é uma doença, não é uma mania, é alcoolismo (como se isso fosse constitutivo desses personagens). Quando ela diz (veja que é ela e não ele) que "menciona" (veja que não é dito, mas mencionado, ou seja, se faz uma menção, o que não é dizer claramente). Mas a menção ganha traços de declaração, de confissão. Ele quer deixar claro, como se o natural fosse esconder. No caso, o alcoolismo coloca-o em situação vulnerável e estigmatizada, como se dissessem que quem trabalha nesse meio sofre com o uso de álcool, drogas etc.

Por essa perspectiva, Lipmann (1973, p. 149) coloca que "não vemos primeiro para depois definirmos, mas primeiro definimos para depois vermos". Isso nos permite observar que a partir de uma preconcepção, o discurso jornalístico em relação ao discurso pornográfico tem o poder de desqualificar o que esteja associado à pornografia. Isso implica dizer que o discurso jornalístico ao falar sobre a pornografia só confirma os estereótipos que já possui na memória discursiva.

No recorte (3) "Separado duas vezes (uma oficial e outra não oficialmente), Fábio conta que o 'emprego não ajudou' nas relações”. Em “emprego não ajudou” é o entrevistado que diz e não a jornalista. No entanto, é ela que faz o recorte do que o entrevistado diz, portanto há uma seleção da entrevista de modo a construir uma coesão discursiva para corroborar como se apresenta o posicionamento da jornalista. A forma com que o discurso é construído coloca o sujeito que trabalha no mercado pornográfico à margem, ainda que visto como "emprego", esse trabalho é tido como 
profissão desprestigiada e marginalizada, espécie de ocupação mal vista pela sociedade, colocando o sujeito em posição estereotipada, como se dissessem que alguém que tenha esse tipo de ocupação não é passível de ter relacionamento sério e/ou duradouro.

Por outro lado, além de dizer sobre a possibilidade de o emprego, focado no sexo, não permitir relações sérias, diz-se justamente o contrário também. Alguém que trabalha estritamente com relações sexuais deveria ter mais condições de manter relações por ter "boa performance" nessa dimensão. As pessoas pensam que quem trabalha no mundo pornográfico faz sexo o dia todo e não tem nenhum problema com a sua sexualidade.

No recorte (4), "solteiro há três anos, Fábio é esclarecido quanto a relacionamentos. 'Eu não me namoraria', admite, 'assim como não namoraria uma mulher que posta todo dia fotos com homens sem camisa. Eu sou muito ciumento"' mais uma vez, o lugar que permeia a fala de Fábio nos possibilita encontrar fragmentos de valores que colocam o discurso pornográfico à margem da sociedade, assim como o discurso machista que estigmatiza a mulher. Isso fica marcado pela contradição do dito que a jornalista selecionou da fala do entrevistado. Ao dizer que não se namoraria ele se coloca no nível de pessoa não confiável e, ao mesmo tempo, coloca a mulher na mesma situação. Isso se aproxima das discussões propostas por Maingueneau (2010) em "O discurso pornográfico".

Enquanto os discursos paratópicos têm "direito de cidadania" (...) a produção pornográfica não é reconhecida pela cidade: idealmente a sociedade não tem conhecimento de sua existência, não se considera que a cidade deva conceder um lugar à pornografia; a cidade nunca erigirá monumentos para seus autores (MAINGUENEAU, 2010, p. 23). 
Ou seja, apesar de existir na sociedade, a pornografia é percebida como discurso atópico e quem circula nesse ambiente é posto em lugar desqualificado. A ocupação dessas pessoas, embora se enquadre nos interstícios de trabalho, não tem prestígio na sociedade como outros tipos de ocupação. Uma das características mais evidentes da pornografia é a sua inserção problemática no espaço social. Segundo Maingueneau (2010) trata-se de produção tolerada, clandestina e noturna.

No último recorte da matéria existe um trecho, (5) "A segunda parte da reportagem será publicada em breve" que segundo nossa análise possui um efeito de sentido que nos leva a questionar a intencionalidade discursiva por trás do texto. Para um jornal, o marcador "em breve" não tem significado consistente. Por se tratar de uma instância que necessariamente trabalha com dados concretos e com datas, esse recorte causa um estranhamento no leitor, que interessado na continuidade da matéria buscaria a continuação nas edições seguintes. Entretanto, o maior estranhamento é que depois de passado um ano da publicação o jornal ainda não tenha publicado a segunda parte da matéria, o que pode ser percebido como uma estratégia mercadológica.

\section{Discurso 2}

A segunda parte do nosso corpus foi extraída do artigo "O pastor e o pornô”, escrito por Anna Virgínia Balloussier, publicado no dia 28 de abril de 2014, na Folha de S. Paulo. A matéria relata a trajetória de Giuliano Ferreira, ex-ator pornô que se converte e se torna pastor. $\mathrm{Na}$ entrevista, Balloussier conta como ele deixou a carreira de ator de vídeos pornográficos para pregar em igreja evangélica. Para compor nossa análise, separamos três recortes da matéria para discutirmos sobre as estratégias que se constroem 
dentro do discurso jornalístico para falar sobre a pornografia e observar como se constituem os posicionamentos que colocam esse discurso em cenário decadente.

(1) Giuliano diz ter contracenado com a ex-chacrete [Rita Cadillac] na frente da câmera e a consolado após o diretor gritar "corta!". "Quem a conhece sabe que a Rita é um personagem, como eu era. Não sou nada daquilo que passava no filme. Ela também não. Era até um pouco tímida. Chorava muito. 'Cara, estou fazendo isso por pura necessidade', dizia. Eu a entendi plenamente. As pessoas pensam que ali atuava um bando de pervertidos. Mas tinha pai e mãe de família buscando o sonho de uma vida melhor."

(2) Hoje, condena qualquer tipo de pornografia - vê seu antigo ramo como uma espécie de "prostituição, segundo a Bíblia". E defende "princípios da família", como casar virgem. "Tenho a certeza que uma pessoa que se casa gostaria de saber que sua esposa não se relacionou com outra pessoa e se guardou somente para ele", diz.

(3) O pastor diz que ainda há quem o olhe de um jeito "meio diferente" nos cultos. Mas que a igreja, no fim, cumpre sua "vocação". "Ela é para acolher, independentemente se é drogado, homossexual, prostituta. O próprio Jesus disse: eu vim para os doentes, não para os sãos", afirma o hoje engravatado pastor Giuliano, com a camisa abotoada até a última casinha. 
(1) "Não sou nada daquilo que passava no filme. Ela também não. Ela era até um pouco tímida. Chorava muito". Amparados por esse fragmento do primeiro recorte vimos a tentativa de justificativa por parte de Giuliano em minimizar um sentimento de culpa por eles terem trabalhado em um tipo de atividade que não é bem vista na sociedade. Sobre esse aspecto Maingueneau (2010, p. 126) salienta que "Tradicionalmente a pornografia era tomada em oposição simples à virtude." Ou seja, apesar de ocupar um lugar em uma indústria financeiramente em ascensão, ainda assim é compreendida como indecente e imoral colocando os envolvidos em situação constrangedora.

O recorte que a jornalista traz reforça a ideia de um lugar de culpa, de arrependimento, de pecado. Pensando na pornografia em oposição à virtude, há um jogo de palavras "As pessoas pensam que ali atuava um bando de pervertidos. Mas tinha pai e mãe de família buscando o sonho de uma vida melhor." que coloca a fala do ator como quem justifica o fato de ter trabalhado na indústria pornográfica fazendo uma oposição entre "um bando de pervertidos e pai e mãe de família," desqualificando as pessoas que trabalham com a pornografia como se fossem todos pervertidos. Dessa forma, distancia-se a prática sexual do contexto familiar, como se pai e mãe não tivessem relação sexual.

No segundo recorte, podemos perceber características na redação da matéria que se assemelham ao que Maingueneau trata por discurso atópico. (2) "Tenho a certeza que uma pessoa que se casa gostaria de saber que sua esposa não se relacionou com outra pessoa e se guardou somente para ele", diz. A atopia aparece como o que não tem lugar legitimado na sociedade, assim como o discurso pornográfico, homofóbico e machista. Neste caso, apesar de tanto o homem quanto a mulher estarem presentes no universo pornográfico, as representações pornográficas eximem de certo modo a 
presença do homem e estigmatizam a figura da mulher, como se ambos não estivessem desenvolvendo o mesmo papel. Com isso, a presença feminina no recorte selecionado tem característica atópica muito mais marcada, o que ressalta Maingueneau (2010, p. 127):

Hoje, em muitos aspectos, não se trata de simples "devassidão", mas de práticas que são remetidas ao universo masculino, tido como um universo que se apóia em uma representação clivada da mulher, a fratura entre a "mamãe" e a "puta".

Isto é, o recorte que o jornal faz pelas palavras do entrevistado coloca a figura da mulher que está em contato com a pornografia como inferior e rebaixada, de forma como se o universo pornográfico tivesse o poder de desqualificar sua essência e dignidade.

Na última parte do recorte, a constituição dos posicionamentos que colocaram a pornografia em lugar marginalizado é percebida quando da disposição das palavras. As pessoas que estão associadas à pornografia são apreendidas como outros grupos que também são discriminados na sociedade. (3) "Ela [a igreja] é para acolher, independentemente se é drogado, homossexual, prostituta. O próprio Jesus disse: eu vim para os doentes, não para os sãos”, Por essa perspectiva, homossexuais, prostitutas e drogados são entendidos como uma só classe, e ainda são chamados de "doentes", o que se pode compreender pelas representações negativadas e marginalizadas. Com isso, percebemos como o discurso jornalístico utiliza dessas estratégias para desqualificar a pornografia e tudo o que a ela esteja associado. Mais uma vez pode-se observar que tais traços estão presentes na fala do entrevistado. Contudo, salientamos que o recorte da entrevista e a organização da matéria para a publicação foi concluída no interior do jornal, ou seja, a jornalista organizou o conteúdo da entrevista de acordo com a intencionalidade da matéria, o que revela a constituição de um posicionamento. 


\section{Considerações finais}

Dentro das limitações que abarcam a nossa pesquisa consideramos que investigar sobre o discurso pornográfico é tratar de um tema muito polêmico, em que se esbarra numa tênue linha entre o lícito e o ilícito, o certo e o errado, dentre outros dualismos.

A partir das propostas aqui levantadas, este trabalho refletiu sobre a constituição dos posicionamentos que se constroem dentro do discurso jornalístico para tratar da representação da pornografia como discurso atópico e marginalizado. Em nossas análises foi possível observar que a percepção da pornografia como discurso atópico se baseia na concepção de Maingueneau (2010) como uma instância que apesar de circular na sociedade não tem um lugar legitimado dentro dos interstícios do espaço social. Ou seja, tomando como exemplo os recortes que utilizamos, as pessoas que estão envolvidas com a pornografia são percebidas a partir de um estigma e de estereótipos que se constroem e se atualizam dentro do discurso jornalístico. Isso pôde ser percebido tanto na pessoa do produtor quanto da atriz e ainda do ex-ator pornô.

Como consequência, a pornografia é associada a características pejorativas e vulgares, vista como indecente e imoral, porém, mesmo marginalizada, ela está presente na sociedade como material de consumo e como produto mercadológico financeiramente em ascensão, o que se pode perceber pela quantidade de materiais do gênero que são produzidos e pelos relatos que foram extraídos do documentário "A primeira vez do cinema brasileiro".

Seguindo a perspectiva do discurso pornográfico visto como clandestino, foi possível identificar estratégias linguístico-discursivas tais como traços que se constroem no jornal para criar representações negativas da pornografia. Entre tais estratégias foram encontrados termos e expressões que desqualificam a pornografia 
e causam um efeito de sentido de rejeição e desvalorização que comprometem seu lugar na sociedade.

Finalmente, podemos concluir que as estratégias utilizadas pela mídia, de certa forma, colocam tanto as pessoas quanto os ambientes onde circulam a pornografia em um lugar periférico, punindo-os por uma conduta equivocada. Pode-se dizer também, que apesar desse olhar estereotipado, a pornografia continua nos interstícios da sociedade, se atualiza e se transforma, como no caso, a produtora Brasileirinhas que busca novas estratégias para permanecer no mercado com novos tipos de conteúdo.

\section{Referências}

CANO, Márcio R. de Oliveira. A manifestação dos estados de violência no discurso jornalístico. São Paulo: PUC-SP, 2012. 185 p. Tese (Doutorado) - Programa de Pós Graduação em Língua Portuguesa - Pontifícia Universidade Católica, São Paulo, 2012.

CHARAUDEAU, Patrick. Discursos da mídia. Trad. Angela S. M. Corrêa. São Paulo: Contexto, 2007.

FOLHA DE S. PAULO. A história da Brasileirinhas, a maior produtora de filmes pornográficos do Brasil (parte 1). (2015) Disponível em: http://www1.folha.uol.com.br/ilustrada/2015/11/1705356-8203a-historia-da-brasileirinhas-a-maior-produtora-de-filmes-pornograficos-do-brasil-parte-1.shtml. Acesso em: 01/08/2016.

FOLHA DE S. PAULO. O pastor e o pornô. (2014) Disponível em: http://religiosamente.blogfolha.uol.com.br/2014/05/28/o-pastor-e-o-porno/ . Acesso em 10/10/2016.

FOUCAULT, M. História da Sexualidade I: a vontade de saber. Trad. M.T. C. Albuquerque e J. A G. Albuquerque. Rio de Janeiro: Graal, 1988. 
LIPMANN, Walter. Estereótipos. In: ROSEMBERG, B. Cultura de Massa. São Paulo: Cultrix, 1973.

MAINGUENEAU, Dominique. Gênese dos discursos. Trad. Sirio Possenti. - São Paulo: Parábola, 2008.

. O discurso pornográfico. Trad. Marcos Marcionilo. - São Paulo: Parábola, 2010.

. Análise de textos de comunicação. 6. ed. ampliada. São Paulo: Cortez, 2013.

. Discurso e análise do discurso. Trad. Sirio Possenti. - São Paulo: Parábola, 2015.

MARCONDES FILHO, Ciro. O capital da notícia. 2a ed. São Paulo: Ática. 1989.

MEDINA, Cremilda. Notícia: Um produto à venda. $4^{\text {a }}$. ed. São Paulo: Summus, 1988. 